\title{
FUNÇÕES PRÓPRIAS DO TRIBUNAL CONSTITUCIONAL E VINCULAÇÃO DOS PRECEDENTES: PARÂMETROS PARA A CONSTITUCIONALIDADE
}

\author{
Thiago Murilo Nóbrega Galvão ${ }^{132}$
}

Recebido em: 06/12/2018

Aprovado em: 26/03/2019

\begin{abstract}
RESUMO
Aborda a relação entre as funções do Tribunal Constitucional e a constitucionalidade das hipóteses de vinculação dos precedentes, conforme previsão do art. 926 e 927 do Novo Código de Processo Civil, enfrentando os questionamentos sobre a inconstitucionalidade das hipóteses do art. 927, do Novo Código de Processo Civil. Igualmente, é tratado as funções próprias da Corte Constitucional e a necessidade de vinculação e estabilidade da jurisprudência constitucional.
\end{abstract}

Palavras-chave: Tribunal Constitucional. Precedentes. Reclamação Constitucional.

\section{INTRODUÇÃO}

As funções da Cortes Constitucional, definidas como próprias, traz consigo a necessidade premente de vinculação dos seus entendimentos. A função estruturante de defesa da hierarquia da Constituição, a função interpretativa e a função arbitral, devem, necessariamente, produzir precedentes obrigatórios, coerentes e estáveis. O destaque, deferido à jurisdição constitucional, não poderá ser reduzir o produto de suas atividades para meros conselhos constitucionais. Pensar desta forma é negar a democracia constitucional.

O Código de Processo Civil de 2015 deferiu elevado destaque aos precedentes judiciais. No livro III "Dos processos nos Tribunais e dos meios de impugnação das decisões judiciais", ganha destaque o Título I "da Ordem dos processos e dos processos de

\footnotetext{
${ }^{132}$ Mestrando em Direito pela Universidade Federal do Rio Grande do Norte - UFRN. Especialista em Direito e Jurisdição pela Escola da Magistratura do Rio Grande do Norte - ESMARN. Especialista em Processo Civil pela UFRN. Especialista em Direito Público pela Universidade de Brasília - UnB. Procurador Federal. ProcuradorChefe do Instituto Federal de Educação, Ciência e Tecnologia do Rio Grande do Norte. Professor da UNI-RN.
} 
competência originária dos tribunais", principalmente o art. $926^{133}$ e $927^{134}$. O art. 926 o CPC de 2015 estabelece dever dos órgãos do Poder Judiciário uniformizar sua jurisprudência, tendo como finalidade a manutenção da estabilidade, integridade e coerência dos precedentes judicias. Em seguida, no art. 927, vincula a atuação dos órgãos que integram o Poder Judiciário às decisões do Supremo Tribunal Federal em controle concentrado de constitucionalidade, aos enunciados de súmula vinculante, aos acórdãos em incidente de assunção de competência ou de resolução de demandas repetitivas e em julgamento de recursos extraordinário e especial repetitivos; os enunciados das súmulas do Supremo Tribunal Federal em matéria constitucional e do Superior Tribunal de Justiça em matéria infraconstitucional; a orientação do plenário ou do órgão especial aos quais estiverem vinculados.

\section{PRECEDENTES COMO FONTES DO DIREITO}

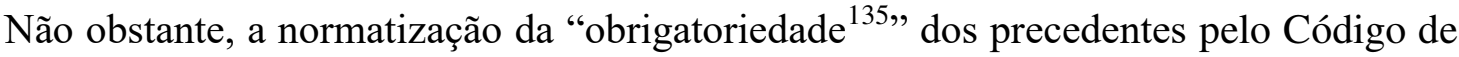
Processo Civil de 2015, a vinculação dos precedentes da Corte Constitucional deriva, antes de qualquer desejo legislativo, implicitamente das funções da jurisdição constitucional, isto porque a rigidez da modificação da norma constitucional136 somada à existência da matriz do controle concentrado de constitucional, atribuem à Corte Constitucional a atribuição de definição da norma constitucional legítima, no exercício de sua função hermenêutica. Assim, a vinculação dos precedentes do Tribunal Constitucional, no exercício de suas funções próprias, seria vinculante pela própria natureza das atribuições da jurisdição constitucional.

Daí se observa que a vinculação derivaria das funções próprias do Tribunal Constitucional, voltado, certamente, para a proteção da jurisdicional constitucional na

133 BRASIL. Código de Processo Civil. Art. 926. Os tribunais devem uniformizar sua jurisprudência e mantê-la estável, íntegra e coerente.

134 BRASIL. Código de Processo Civil. Art. 927. Os juízes e os tribunais observarão:

I - as decisões do Supremo Tribunal Federal em controle concentrado de constitucionalidade;

II - os enunciados de súmula vinculante;

III - os acórdãos em incidente de assunção de competência ou de resolução de demandas repetitivas e em julgamento de recursos extraordinário e especial repetitivos;

IV - os enunciados das súmulas do Supremo Tribunal Federal em matéria constitucional e do Superior Tribunal de Justiça em matéria infraconstitucional;

V - a orientação do plenário ou do órgão especial aos quais estiverem vinculados.

135 BRASIL. Código de Processo Civil. Redação do art. 927.

136 BRASIL. Constituição Federal. Art. 60. A Constituição poderá ser emendada mediante proposta:

I - de um terço, no mínimo, dos membros da Câmara dos Deputados ou do Senado Federal; 
incumbência de proteção à democracia constitucional, conforme já alertado em parágrafos pretéritos.

Logo, no regime de democracia constitucional, os sistemas das funções dos Poderes da República deverão ser observados com temperamento. Nenhuma função poderá se sobrepor as demais, sob pena de violação do alicerce central da divisão do Poder Político do Estado, a harmonia e a independência entre as funções do estado ${ }^{137}$.

$\mathrm{Na}$ tessitura do Estado Constitucional, as funções do Estado se entrelaçam em laços harmônicos de tal maneira que as funções podem exercer atribuições não típicas, como a função administrativa realizada pelo Poder Legislativo e pelo Poder Judiciário, a função legislativa exercida pelo Poder Executivo ${ }^{138}$, o fenômeno da delegificação ${ }^{139}$, entre exemplos. Não obstante a harmonização pretendida pela democracia constitucional, certamente, o núcleo central de cada função estatal deverá ser preservado. Disso resultam as palavras de MADUREIRA (2017, pag. 205):

\begin{abstract}
A adoção de precedentes como parâmetros para a aplicação do direito traduz, em verdade, uma integração entre as funções exercidas pelo Poder Legislativo ("criar direito como legislador na moldura da Constituição") e pelo Poder Judiciário ("reconstruir direito como juiz dentro do processo de interpretação"), num contexto em "que a vinculatividade formal dos precedentes reduz o espaço de discricionariedade dos juízes e ao mesmo tempo garante mais racionalidade, previsibilidade e igualdade no direito".
\end{abstract}

A proteção aos valores do Estado Liberal, função atribuída à sociedade através dos seus representantes - Parlamento, deferiu a ele a proteção da igualdade, proteção à propriedade, segurança jurídica, previsibilidade das normas jurídicas e das condutas estatais. Não obstante, conforme já abordado, a jurisdição constitucional assume, na democracia constitucional, relevo e destaque sendo também órgão produtor da norma jurídica, esse contexto desloca para o Poder Judiciário e para a Corte Constitucional problemas anteriormente reservados apenas ao Poder Legislativo. Com efeito, as decisões judicias devem ter previsibilidade, segurança jurídica, promoção da igualdade, coerência e estabilidade. Assenta LEITE e BREITENBACH (2016, p. 224):

137 BRASIL. Constituição Federal. Art. $2^{\circ}$ São Poderes da União, independentes e harmônicos entre si, o Legislativo, o Executivo e o Judiciário.

138 BRASIL. Constituição Federal. Art. 62. Em caso de relevância e urgência, o Presidente da República poderá adotar medidas provisórias, com força de lei, devendo submetê-las de imediato ao Congresso Nacional. (Redação dada pela Emenda Constitucional n ${ }^{\circ} 32$, de 2001)

139 VALLE, Vanice Regina Lírio do. Delegificação, Legitimidade e Segurança Jurídica: a Hermenêutica Constitucional como Alternativa de Harmonização. Revista de Direito Administrativo \& Constitucional. Dez. 2004 
Nesse sentido, tais exigências também se dirigem aos juízes e Tribunais, os quais passam a ter uma responsabilidade institucional no que diz respeito à estabilidade, consistência e transparência dos critérios empregados na interpretação jurídica. Assim, também se espera segurança e previsibilidade das Cortes quanto ao seu modus operandi, não sendo compatíveis com o paradigma do Estado Constitucional decisões arbitrárias, casuístas e irracionais.

Neste cenário, observa-se a materialização da estabilidade dos precedentes na matriz de controle difuso de constitucional pelos órgãos que integram o Poder Judiciário. Com efeito, é função estruturante da Corte Constitucional revelar, em última palavra, a norma constitucional. Logo, não se revela coerente e adequado provimentos judiciais contrários aos precedentes julgados pelo Tribunal Constitucional, isto porque geraria normas constitucionais diversas de um mesmo direito fundamental, conforme assenta MADUREIRA (2017, pag. 205):

\footnotetext{
Essa necessidade é inquestionável nos regimes que admitem o controle difuso da constitucionalidade, como no Brasil; contexto em que "não há como admitir que um juiz de primeiro grau de jurisdição, ou mesmo qualquer tribunal, possa decidir mediante uma concepção de direito fundamental destoante da que lhe tenha sido atribuída pelo Supremo Tribunal Federal".79 Não se trata, aqui, de decisões que fazem "coisa julgada erga ommes, própria às ações em que o controle de constitucionalidade é concentrado, ou em súmula vinculante", mas da vinculatividade das decisões tomadas pelo Excelso Pretório em controle difuso, pois o "Judiciário não pode legitimamente conviver com concepções diversas e antagônicas acerca de um direito fundamental, máxime quando o seu significado já foi definido pelo Supremo".
}

A obrigatoriedade dos precedentes judiciais, nos moldes imaginados pelo Código de Processo Civil de 2015 é a exata sedimentação da função da jurisdição constitucional. A vinculação ou obrigatoriedade de observância dos precedentes da Corte Constitucional não deriva do desejo do legislador, mas antes disso, decorre, em verdade, da própria natureza jurídica da jurisdição constitucional, cujo fundamento decorre do próprio movimento fundante do Poder Constituinte. O contexto, da obrigatoriedade dos precedentes do Tribunal Constitucional, é movimento que deve ser enxergado como limitador da definição do conteúdo norma jurídica, pelos demais órgãos do Poder Judiciário. Em outras palavras, a discricionariedade encontra-se limitada.

A conjuntura de limitação da discricionariedade das manifestações dos órgãos do Poder Judiciário decorre da complexidade das relações sociais e, consequentemente, da opção legislativa pela adoção de conceitos jurídicos indeterminados, princípios jurídicos e cláusulas abertas. Não é raro a moldura normativo, fixada pelo legislador, deferir, ao órgão prolator do provimento judicial, ampla liberdade. A liberdade, contudo, não significa arbitrariedade de tal sorte a permitir interpretações dissociadas do Tribunal Constitucional, sob pena de subverter a 
própria natureza da Jurisdição Constitucional. Neste mesmo sentido LEITE e BREITENBACH (2016, p. 226):

\begin{abstract}
Ao colocar o precedente como fonte do direito, o intuito é restringir os poderes dos magistrados. Mesmo se entendermos que o reconhecimento da necessidade de seguir um precedente criado pelo Poder Judiciário é uma limitação mitigada ao poder criativo do juiz se comparada com a possibilidade de limitação decorrente daquilo que é criado pelo legislador, ao vincular a atividade judicial ao que está contido nos precedentes, inexoravelmente restam constrangidos a discricionariedade e o arbítrio judicial.
\end{abstract}

De outro lado, não se pode negar que os provimentos da Corte Constitucional, independentemente da matriz de controle de constitucionalidade, concentrado ou difuso, tem natureza jurídica de fonte do direito, mas não são meras coadjuvantes, como apontava a tradicional dogmática jurídica, FERRAZ JR (2003, P. 244). A relevância da Jurisdição Constitucional defere aos provimentos judicias papel que vai além do mero auxílio do direito. Sobre a jurisprudência TARUFFO (2014, p. 3):

\begin{abstract}
é a jurisprudência que constitui o conteúdo efetivo do chamado direito vivo, o qual representa, em muitos casos, o único direito do qual dispomos - por exemplo, quando os juízes criam direito para preencher lacunas - ou o verdadeiro direito do qual dispomos - quando os juízes criam direito interpretando cláusulas gerais ou qualquer outro tipo de norma.
\end{abstract}

No mesmo sentido, sobre a relevância da jurisprudência como fonte do direito NOBRE JUNIOR (2000, p. 157):

\begin{abstract}
Após reconhecer a inevitabilidade da função criadora do julgador hodierno, Cappelletti, em brilhante distinção, apartou, com base nas diferenças entre os processos legislativo e jurisdicional, a criatividade judicial da atividade de fazer leis. O diferencial reside, portanto, na conexão da atividade decisória com a solução de casos concretos, bem como na atitude de imparcialidade do juiz.
\end{abstract}

A transformação da jurisprudência, de fonte coadjuvante do direito para fonte direta e primária do Direito, deriva da própria natureza da Jurisdição Constitucional e das funções do Tribunal Constitucional, por isso, as manifestações da Corte Constitucional se revelam como fonte direta e imediata o direito ${ }^{140}$, seja através do efeito vinculante seja através da obrigatoriedade dos precedentes.

\footnotetext{
${ }^{140}$ Exemplificando: Em sessão do dia 27 de outubro de 2015, o Plenário do Supremo Tribunal Federal, no julgamento do Recurso Extraordinário 693.456/RJ, julgado sob sistemática da repercussão geral, cujo teor aferiu a constitucionalidade do desconto dos dias parados em razão de greve de servidor público. O precedente tem natureza de obrigatório, vinculante apenas o Poder Judiciário, contudo, a Advocacia-Geral da União, com fundamento nas razões de decidir, através do Parecer $n^{\circ}$ 004/2016/CGU/AGU, aprovado pelo Advogado-Geral da União, aprovado em seguida pelo Presidente da República, estendeu para a Administração Pública Federal. BRASIL. Advocacia-Geral da União. Publicado 13 de dezembro de 2016.
} 


\section{HIPÓTESES DE VINCULAÇÃO DOS PRECEDENTES}

Sendo esse o contexto, o art. 926 cumulado com o art. 927, I e II, seriam indubitavelmente constitucionais, conforme já alertado em momentos anteriores deste trabalho. A hipótese de incidência prevista no inciso III, do art. 926, “acórdãos em incidente de assunção de competência" tem nítida relação com a função arbitral, tendo natureza de função própria do Tribunal Constitucional, a segunda hipótese contida no inciso " "resolução de demanda repetitivas e em julgamento de recursos extraordinário e especial repetitivos". O julgamento de recursos extraordinários repetitivos, tem, outrossim, relação com a função própria estruturante do Tribunal Constitucional, no caso a função interpretativa e, de certa forma, o controle de controle constitucionalidade, mas na matriz difusa.

A vinculação aos julgamentos de recursos especiais repetitivos - inciso III, art. 927, NCPC, e a súmula persuasiva do Superior Tribunal de Justiça, não tem relação com a função do Tribunal Constitucional, contudo, não é objeto do presente trabalho, motivo pelo qual o tratamento sobre essa temática será objeto de trabalho futuro.

O legislador, ao elencar como obrigatoriedade de observação dos enunciados das súmulas persuasivas do Supremo Tribunal Federal em matéria constitucional - inciso IV, do art. 927, do NCPC, alavancou discussão doutrinária sobre a legitimidade constitucional desta hipótese de vinculação.

Assenta CRUZ e TUCCI (2015, p. 454), assenta que o efeito vinculante somente seria possível nos limites estabelecidos pela Constituição Federal, no caso para súmulas vinculantes e aos julgados originados de controle abstrato de constitucionalidade. Da mesma forma NERY JUNIOR e NERY (2005, p. 1.156).

As críticas sobre a obrigatoriedade e a vinculação dos precedentes judiciais recebe resistência, conforme percebido por NOBRE JUNIOR (2000, p. 156):

\footnotetext{
Não constitui pretensão deste breve escrito, no que concerne aos pontos adversos da vinculação, proceder a uma abordagem exaustiva. Concentraremos nossas atenções sobre cinco aspectos, quais sejam: a) a afronta à separação de poderes; b) o aniquilamento da independência judicial; c) a petrificação do direito; d) a violação ao juiz natural; e) a incompatibilidade do instituto com os sistemas da família romano-germânica.
}

É de se observar, contudo, que a vinculação dos precedentes da Corte Constitucional decorre da própria função típica, deferida pela jurisdição constitucional. Logo, a natureza da função estruturante de controle de constitucionalidade e da manutenção de hierarquia 
normativa da Constituição, denota vinculação dos seus precedentes, sem demandar previsão expressa para tanto.

Assim, a opção feita pelo Poder Constituinte Derivado Reformador, ao estabelecer o efeito vinculante aos precedentes em controle abstrato de constitucionalidade ${ }^{141}$ e à súmula vinculante $^{142}$, tem natureza jurídica de meros exemplos de precedentes vinculantes, não são taxativas, até porque pensar em limitação da jurisdição constitucional seria contrariar a própria razão de sua existência, como elemento de proteção para a sociedade, notadamente na sua função contramajoritária e de proteção da hierarquia da Constituição.

Em complementação, a vinculação das demandas de assunção de competência, prevista no art. 927, III, primeira parte, do Código de Processo Civil, decorrente da função arbitral inerente à Corte Constitucional, não por outro motivo que a violação da competência do Tribunal Constitucional é hipótese de cabimento da reclamação constitucional ${ }^{143}$. A finalidade essencial é a proteção das atribuições do Tribunal Constitucional, preservando sua função arbitral, com natureza de função própria.

No tocante a segunda parte do art. 927, III, do NCPC, a vinculação dos demais órgãos do Poder Judiciário, aos precedentes julgados em decorrência de recurso extraordinário repetitivo, decorre, também da função própria da Corte Constitucional, no caso a função interpretativa.

Não custa assinalar, como afirmado linhas atrás, com base no magistério do Eros Roberto Grau, o texto normativo não se confunde com a norma. Assim, o texto normativo da Constituição não se confunde com a norma constitucional, produto da função interpretativa do Tribunal Constitucional.

Com efeito, a demonstração da norma, através do exercício da hermenêutica, não poderá relegar os precedentes judicias à mera fonte auxiliar do direito, como é tradição dos

141 BRASIL. Constituição Federal. Art. 103-A. O Supremo Tribunal Federal poderá, de ofício ou por provocação, mediante decisão de dois terços dos seus membros, após reiteradas decisões sobre matéria constitucional, aprovar súmula que, a partir de sua publicação na imprensa oficial, terá efeito vinculante em relação aos demais órgãos do Poder Judiciário e à administração pública direta e indireta, nas esferas federal, estadual e municipal, bem como proceder à sua revisão ou cancelamento, na forma estabelecida em lei. (Incluído pela Emenda Constitucional $n^{\circ} 45$, de 2004) (Vide Lei n 11.417, de 2006).

142 BRASIL. Constituição Federal. Art. 102. Compete ao Supremo Tribunal Federal, precipuamente, a guarda da Constituição, cabendo-lhe: $\S 2^{\circ}$ As decisões definitivas de mérito, proferidas pelo Supremo Tribunal Federal, nas ações diretas de inconstitucionalidade e nas ações declaratórias de constitucionalidade produzirão eficácia contra todos e efeito vinculante, relativamente aos demais órgãos do Poder Judiciário e à administração pública direta e indireta, nas esferas federal, estadual e municipal. (Redação dada pela Emenda Constitucional $n^{\circ} 45$, de 2004)

143 BRASIL. Constituição Federal. Art. 102. Compete ao Supremo Tribunal Federal, precipuamente, a guarda da Constituição, cabendo-lhe: I - processar e julgar, originariamente: 1) a reclamação para a preservação de sua competência e garantia da autoridade de suas decisões; 
sistemas jurídicos da família romano-germânico, principalmente diante das atribuições da jurisdição constitucional.

Logo, a função interpretativa, núcleo central da segunda parte do Art. 927, III, do NCPC, tem sua constitucionalidade testada, com sucesso, nas funções próprias da Cortes Constitucional e da jurisdição constitucional. Daí se vê que, a obrigação da obrigatoriedade dos precedentes fixados em recurso extraordinário repetitivo não violação o modelo constitucional de divisão de atribuições entre os Poderes do Estado.

Por conseguinte, as hipóteses dos incisos IV do art. 927, do NCPC, tem, outrossim, relação com a função interpretativa do Tribunal Constitucional. Contudo, as súmulas persuasivas, elaboradas pelo Supremo Tribunal Federal, encontram-se em desuso. A última súmula persuasiva do Supremo Tribunal Federal foi a $n^{\circ} 736^{144}$, aprovada na sessão plenária de 26 de novembro de 2003, publicada no Diário da Justiça nos dias 09 de dezembro de 2003, 10 de dezembro de 2003 e 11 de dezembro de $2003^{145}$.

A vinculação dos precedentes do controle abstrato de constitucionalidade, bem como a adoção da Súmula Vinculante, com a Emenda Constitucional $n^{\circ} 45 / 2006$, deferiram ao Supremo Tribunal Federal instrumento necessário e mais eficazes para a proteção e coerência dos seus precedentes.

Assim, a elaboração de súmula persuasiva, fora das circunstâncias dos incisos I, II, III, do art. 927, do NCPC, ficou sensivelmente esvaziada, pode-se cogitar, entretanto, a utilização de súmulas persuasivas para competências do Supremo Tribunal Federal, com natureza imprópria, como as competências do art. 102, I, "c"; Art. 102, I, "d" - Mandado de Segurança contra atos do Tribunal de Contas da União; art. 102, I, "f" - conflitos entre entidades da Administração Indireta; art. 102, I, “g” - extradição solicitada por Estado estrangeiro; art. 102, I, “q" - Mandado de Injunção quando a elaboração da norma regulamentadora for atribuição do Tribunal de Contas da União; art. 102, II, referente à competência recursal ordinária.

É de se alertar, contudo, que as atribuições sobreditas decorreram do desejo do constituinte originário, não são competências caracterizadas como naturais do Tribunal Constitucional, são caracterizadas, por isso, como funções impróprias, conforme alertado em parágrafo pretéritos.

144 BRASIL. Supremo Tribunal Federal. Súmula 736: “Compete à Justiça do Trabalho julgar as ações que tenham como causa de pedir o descumprimento de normas trabalhistas relativas à segurança, higiene e saúde dos trabalhadores". 
Ademais, é necessário alertar que existe sensível distinção entre a súmula persuasiva e a súmula vinculante. É que a súmula vinculante obriga a Administração e o Poder Judiciário, a súmula persuasiva, nos termos do art. 927, do Código de Processo Civil, vincularia apenas os órgãos do Poder Judiciário. Assenta MADUREIRA (2017, pag. 204):

\begin{abstract}
Está claro, então, que o legislador, quando concebeu o texto do art. 927 do Código de 2015, para além de não haver abdicado da sua prerrogativa de construir normas gerais e abstratas (porque apenas conferiu aos julgadores a concepção, sob a forma de precedentes, de normas abstratas de conteúdo concreto), também não criou uma nova súmula vinculante, e por isso não modificou o regramento constitucional relativo à matéria.
\end{abstract}

Ainda sobre a hipótese do inciso IV do art. 927, do NCPC, é necessário apontar que a obrigatoriedade da súmula persuasiva não decorre da redação da súmula, mas sobretudo das razões fundamentais que originaram a norma jurídica. Vale dizer, o enunciado da súmula não obriga ou vincula, a observância decorre, em verdade, do exercício hermenêutico realizado pela Corte Constitucional, na fixação da moldura normativa do possível. Neste sentido, LEITE e BREITENBACH (2016, p. 227):

\begin{abstract}
Como se percebe, foi prevista a necessidade de observância dos precedentes para edição das súmulas. Em face disso, e até que o sistema de precedentes esteja em perfeito funcionamento e em harmonia com o ordenamento jurídico, é possível concluir que os Tribunais, na edição das súmulas, deverão observar a ratio decidendi dos precedentes que justificaram a atividade administrativa de edição de súmulas. Observar os enunciados das súmulas, conforme previsto nos incisos $\mathrm{II}$ e $\mathrm{V}$, do art. 927, do CPC/2015, "é observar a ratio decidendi dos precedentes que os originaram - fala-se em observância do enunciado apenas por uma opção pela brevidade e pela facilitação do discurso" (DIDIER JR.; BRAGA; OLIVEIRA, 2015, p. 464). Em razão de entendemos ser necessária a proclamação da ratio decidendi pelo próprio Tribunal que julga o caso concreto gerador do precedente, conforme se verá a seguir, entendemos que essa atividade também pode ser adequadamente realizada mediante a edição de enunciados de súmulas, isso até que, paulatinamente, a técnica seja abandonada e esteja instituído o adequado sistema de precedentes. Com efeito, tendo em vista ser quase impossível o STF e o STJ simplesmente renunciarem ao direto de editar súmulas, há necessidade de eliminação gradual delas, até a completa extirpação do sistema e substituição por leading case, que são muito mais ricos na enunciação do contexto-fático jurídico em que se formou a decisão paradigmática (NOGUEIRA, 2013, p. 248-249).
\end{abstract}

Por conseguinte, no tocante à hipótese do inciso $\mathrm{V}$ do art. 927, do CPC-15, é necessário, ainda, assinalar que os julgamentos do Tribunal Constitucional, no uso das competências impróprias - funções impróprias, deferidas ao Supremo Tribunal Federal, por força do Poder Constituinte - originário ou derivado, não poderiam ser obrigatórias por força do art. $927, \mathrm{~V}$, do CPC.

Emerge, como exemplo, a competência prevista no art. 102, I, “d”, da Constituição Federal, deferida ao Supremo Tribunal Federal. A competência do STF para julgamento do 
Mandando de Segurança contra ato do Tribunal de Contas da União, poderá provocar uma incongruência no sistema de competências do Superior Tribunal de Justiça e eventual conflito com a vinculação dos precedentes, nos termos do Art. 927, do CPC. De fato, o Superior Tribunal de Justiça poderá, na sistemática dos recursos repetitivos, julgar pretensão referente à legitimidade de algum direito ou vantagem de servidor público. A decisão terá efeito vinculante, por força do art. 927, III. O mesmo tema, contudo, poderá ser objeto de análise pelo Supremo Tribunal Federal, quando o Tribunal de Contas da União, apreciando o mesmo tema fixar determinado entendimento contrário ao interesse do servidor, o que poderá ensejar impugnação da decisão do Tribunal de Contas da União através Mandado de Segurança, atraindo, assim, a competência do Supremo Tribunal Federal.

\title{
3.1 Princípio da segurança jurídica
}

É de se notar que a atividade interpretativa poderá resultar na produção de diversas normas, dentro da moldura normativa possível. Logo, a estabilização, certeza e a segurança jurídica são categóricos necessários à estabilidade das relações.

Não por outro motivo que (NOBRE JUNIOR, 2000, p. 155):

\begin{abstract}
O sistema do stare decisis, não se pode notar, produz valiosos resultados em prol dos jurisdicionados. Em primeiro lugar, a utilização dos precedentes implica assegurarse a concretização do ideal de certeza do direito, de maneira que se pode antever, dadas as particularidades dos litígios, qual a solução a ser adotada pelo Judiciário. Isso homenageia um dos princípios mais caros ao Constituinte, quando da estruturação do sistema jurídico nacional, qual seja o da segurança jurídica. Noutra vertente, o efeito vinculante responde, perante a sociedade de massa, em que um só comportamento poderá afetar a esfera subjetiva de inúmeras pessoas, à exigência de se assegurar a igualdade de tratamento em hipóteses iguais. A isonomia, é bom que se diga, constitui meta primordial de qualquer Estado que se organize sob as vestes democráticas, sem contar que se cuida de modelo de justiça aspirado desde as origens mais remotas da civilização.
\end{abstract}

Acrescenta, ainda, o NOBRE JUNIOR (2000, p. 156), sobre a necessidade de coerência das orientações jurisprudenciais:

Visto isso, acrescente-se que o efeito vinculante se justifica pela necessidade de coerência das orientações jurisprudenciais, de sorte que somente poderão ser alteradas quando houver relevante motivo. Ademais, não posso perder a lembrança do afirmado por José Augusto Delgado quando, a pretexto de justificar a sua simpatia pelo tão amaldiçoado instituto, invocara, em desfavor de pruridos doutrinários, o ideal, atualmente cristalizado como sentimento idílico da sociedade brasileira, do acesso à justiça, a propiciar que a prestação jurisdicional perseguida pelo cidadão seja, com segurança e rapidez, tornada realidade. 
Logo, a atividade, antes exercida pelo Legislador, na acepção política, de exercer a seletividade dos fatos sociais que mereceriam tratamento normativo, foi de certa forma transferida para o Poder Judiciário, em decorrência, sobretudo, das opções e técnica legislativas, como conceitos jurídicos indeterminados, cláusulas abertas, princípios. Dada a assunção, pela Jurisdição Constitucional, de atribuição do real sentido das normas, como resultado da atividade interpretativa, não poderia, a democracia constitucional, deferir tal competência para todos os órgãos do Poder Judiciário, as tensões entre as funções da república seriam catalisadas. Em razão disso, a atribuição de atribuir estabilidade e coerência deve ser reservada ao Tribunal Constitucional.

\title{
3.2 Acesso à justiça
}

CAPPELLETTI (2008, p. 161), ao explicar as dimensões do acesso à justiça, aponta à jurisdição constitucional função de destaque no acesso à justiça:

\begin{abstract}
Uma análise dos principais acontecimentos e das grandes tendências evolutivas nos ordenamentos jurídicos contemporâneos expôs à luz três movimentos fundamentais de ação e de pensamento. Pode-se, portanto, falar de três dimensões do direito e da justiça no mundo contemporâneo. Trata-se, antes de tudo, da dimensão "constitucional", que se percebe no reencontro com alguns valores fundamentais que muitos ordenamentos modernos afirmaram como normas com força de lex superior, que vinculam também ao legislador (ordinário), muitas vezes, impondo-lhe o respeito mediante formas e mecanismos jurisdicionais especiais. Foi assim que surgiu o fenômeno da grande difusão da jurisprudência constitucional.
\end{abstract}

Com efeito, o Poder Judiciário, na configuração moderna do Estado assumiu, tal qual as demais funções, a atribuição de efetivar o modelo constitucional de sociedade. A consequência, da assunção de parte das atribuições do Estado, antes deferidas apenas à função legislativa (Poder Legislativo) e à função administrativa (Poder Executivo), teve como consequência a ampliação das atribuições do Poder Judiciário o que acarretou aumento do volume das demandas judiciais. CAPPELLETTI (2008, p. 164):

\footnotetext{
Assinalamos o fenômeno do "gigantismo jurisdicional", conseqüência direta da renovação e ampliação das tarefas "sociais" do Estado, antes restritas pela função judicial, que porém são também consequiência indireta do alargamento do "acesso" aos órgãos jurisdicionais, e, mais ou menos amplamente, realizadas pelas duas "ondas" do movimento para alcançar o acesso à justiça, descrito no parágrafo precedente.
}

CAPPELLETTI (2008, p. 164), aponta, outrossim, efeitos não desejáveis inerentes ao fenômeno de judicialização dos direitos, a sobrecarga dos órgãos judiciais, baixa qualidade dos procedimentos e das decisões judiciais: 
Dito fenômeno, por outra parte, tornou-se particularmente preocupante, não tanto, ou não somente, por razões quantitativas (a sobrecarga dos órgãos judiciais, que levada ao extremo pode provocar uma verdadeira paralisia), mas também e acima de tudo, por razões qualitativas. O excesso de trabalho pode freqüentemente traduzir-se em uma baixa de qualidade dos procedimentos e das decisões judiciais.

Sendo esse o contexto, o direito a justiça mais acessível deverá configurar, em resposta ao que CAPPELLETTI definiu como gigantismo judicial, conjunto de procedimentos e meios para permitir uma justiça mais acessível, CAPPELLETTI (2008, p. 165):

É aqui onde se manifesta a terceira e mais recente - porém também mais complexa e, talvez, potencialmente, mais grandiosa "onda" do movimento mundial por um direito e uma justiça mais acessíveis. Tal onda de reformas, que se encontra ainda em uma fase inicial e experimental e que somente como resultado de uma análise superficial pode aparecer em contraste com as outras duas, se traduz em múltiplas tentativas de acordo, na perseguição de fins distintos, porém relacionados entre eles de várias formas e maneiras. Entre esses ressaltam-se: a) os fins que estabelecem procedimentos mais acessíveis quanto a sua simplicidade e racionalização, mais econômicos, eficientes e especializados para certos tipos de controvérsia; b) o fim de promover e fazer acessível um tipo de justiça que, em outra parte, definimos como "co-existencial", quer dizer: baseada na conciliação e mediação, e sobre critérios de equiidade social distributiva, uma vez que se revela importante "cuidar" das situações complexas e duradouras decorrentes da correlação entre indivíduos e grupos, em lugar de apenas "definir" simplesmente (trancher) uma posição determinada, com rígidos critérios jurídicos, ao estilo "com razão"/"sem razão", essencialmente voltados ao passado; c) o fim de submeter a atividade pública a formas, muitas vezes novas e de qualquer modo mais alargadas e acessíveis, de controle; e, em geral, de criar formas de justiça mais acessíveis enquanto mais descentralizadas e "participativas", com a presença, em particular, dos membros desses mesmos grupos sociais e comunidades que estão diretamente envolvidos na situação ou controvérsia. É precisamente pelo surgimento desta última finalidade que um dos temas de maior interesse teórico e prático apareceu recentemente na participação de leigos na administração da justiça. CAPPELLETTI (2008, p. 165)

Logo, o efeito vinculante, a obrigatoriedade dos precedentes do Tribunal Constitucional, bem como a Reclamação Constitucional, são efusivamente resposta à determinação constitucional do acesso à justiça. A fixação de teses ou molduras normativas, pela Corte Constitucional, permitirá tempestividade do acesso à ordem justa, sem entraves e burocracias desnecessárias.

\subsection{Processo como igualdade}

A vinculação ou obrigatoriedade dos precedentes promove, ainda, a igualdade das partes perante a decisão judicial. Neste sentir LEITE e BREITENBACH (2016, p. 225):

Nesse cenário, o direito processual sempre teve a tendência de se preocupar com a igualdade no processo (= igualdade de tratamento no interior do processo) e com a 
igualdade ao processo (= simétrica disponibilidade de técnicas processuais). Somente nos últimos anos é que, no entanto, o processo foi dotado de mecanismos para assegurar a igualdade perante as decisões. Com efeito, não basta mais utilizar o processo apenas como instrumento de mediação de conflitos. O processo deve ser encarado como instrumento positivo de efetivação dos anseios da sociedade, não servindo apenas como instrumento de aplicação de preceitos legais, mas também de conformação e adequação do direito material ao caso concreto.

\section{A RECLAMAÇÃo CONSTITUCIONAL COMO INSTRUMENTO DE PROTEÇÃO E DEFESA DA JURISDIÇÃO CONSTITUCIONAL}

Descrito o panorama das funções da Corte Constitucionais, notadamente diante do sistema de divisão de atribuições dos Poderes do Estado, bem como o efeito vinculante dos precedentes judiciais voltaremos nossa preocupação, neste tópico, para demonstrar a reclamação constitucional como instrumento de defesa das funções da Corte Constitucional.

Os atos judiciais emanados com fundamento na função estruturante da Corte Constitucional devem possuir ampla efetividade, ou seja, devem revelar suficiência por si só, sem a necessidade de qualquer instrumento suplementar para o cumprimento da decisão. Os provimentos judiciais do Tribunal Constitucional, no exercício das atribuições inerentes à jurisdição constitucional, devem ser efetivos e vinculantes. Trata-se da própria ideia fundante da hierarquia da Constituição.

A norma constitucional, revelada através do exercício de hermenêutica, decorre da exata compreensão do texto normativo e do contexto em que a norma está inserida. Emerge, pois, como atribuição do Tribunal Constitucional demostrar os exatos termos das normas constitucionais, por isso, as decisões da Corte Constitucional tem natureza jurídica de norma constitucional (TAVARES, 2006, p. 24), e, assim sendo, tem efeito obrigatório para os demais órgãos do Poder Judiciário.

A manutenção das funções do Tribunal Constitucional - função interpretativa e função de manutenção da hierarquia da Constitucional com o controle de constitucionalidades, somente poderão ser materializadas diante de um cenário de hierarquia e efetividades dos provimentos da Corte Constitucional, sendo efetiva e vinculante, pela natureza jurídica da jurisdição constitucional, aos demais órgãos do Poder Judiciário e demais poderes. Caso contrário, as manifestações da jurisdição constitucional teriam apenas força persuasiva, como consequência, transformaria as atribuições da Corte Constitucional em conselhos constitucionais, nada mais impróprio para a missão da dogmática constitucional. 
Daí se percebe a necessidade, no direito constitucional, da presença de instrumento adequado para manutenção e proteção das funções do Tribunal Constitucional.

Ademais, a proteção da função arbitral, cujo conteúdo visa a proteção do regime de competências prevista na Constituição, denota a mesma proteção, principalmente porque a usurpação de competências, pelos demais órgãos do Estado poderá gerar tensões graves entre os Poderes do Estado ou entre os integrantes da Federação.

Ao conceber a jurisdição constitucional, enquanto sistema de proteção da democracia Constitucional, na forma teórica das funções do Tribunal Constitucional, a dogmática constitucional deverá oferecer instrumentos adequados para a defesa e proteção desse sistema. Daí o contexto constitucional aloca a Reclamação Constitucional, como instrumento processual de defesa da jurisdição constitucional.

A ideia de existência da Reclamação Constitucional significa eventual fragilidade do ordenamento jurídico, com clara demonstração de baixa efetividade, uma vez que os pressupostos da reclamação são justamente fatos que denotam a vulnerabilidade das decisões judicias ou pior a usurpação de competência constitucionalmente, assegurada.

A liberdade interpretativa, deferida pela dogmática constitucional, principalmente com a escolha de textos normativos com conteúdo jurídico indeterminado ou cláusulas abertas, conferiu liberdade interpretativa ao órgão julgado. Em outras palavras, a moldura normativa do juridicamente possível foi sensivelmente ampliada. Não raro, na aplicação das normas constitucionais, os órgãos do Estado, separam todo conteúdo da norma, para ao final chegar a uma conclusão fortuita de interpretação.

Assenta HORBACH (2007, p. 81):

\begin{abstract}
$\mathrm{Na}$ interpretação da lei ou da Constituição, os 'neo-constitucionalista' separam a termo do conceito, o conceito do preceito, o preceito da norma, a norma do texto e o texto do contexto, para, ao final dessa operação, fazer com que o dispositivo afirme exatamente o que desejam e, não raro, o contrário do que nele está escrito.(HORBACH, 2007, p. 81)
\end{abstract}

Percebe-se, por isso, que a previsão da Reclamação Constitucional demonstraria fragilidade do sistema de jurisdição constitucional, isto porque no exercício da jurisdição constitucional, a efetividade das decisões do Tribunal Constitucional e a proteção das normas relativas a competências não estariam tão claras ou os interpretes estariam ultrapassando a moldura normativa do juridicamente possível.

Não enxergo, todavia, fragilidade do sistema jurisdicional. A existência da Reclamação Constitucional, como meio processual para a proteção da jurisdição constitucional, não deixa o sistema vulnerável. A percepção da solidez da jurisdição 
constitucional não decorre exclusivamente dos meios processuais disponíveis para a preservação e a efetividade dos provimentos judiciais da Corte Constitucional. Se assim fosse o sistema recursal, como meio de revisão das decisões judiciais, também seria caracterizado como falha ou equivoco procedimental ou interpretativo.

$\mathrm{Na}$ verdade, a imperfeição do sistema jurisdicional está alocado na imperfeição do capital humano. Conforme destaca o Professor. Dr. Marcelo Navarro Ribeiro Dantas: "Sem que mudem, melhorem, os homens, não mudará o Estado, não mudará o Direito, não mudará o processo, não se superará essa famosa crise". (NAVARRO, 2001, p.502-4).

Assim, conquanto sua previsão esteja sedimentada em fragilidades do sistema jurisdicional, a reclamação constitucional deve ser vista como importante instrumento para a materialização da democracia constitucional, ao instrumentalizar a defesa e proteção das funções do Tribunal Constitucional, como a proteção da função arbitral - hipótese de cabimento de proteção da competência ou garantia da autoridade de suas decisões ${ }^{146}$.

\section{CONSIDERAÇÕES FINAIS}

A superioridade da concepção estritamente democrática, do governo da maioria, do exercício das prerrogativas políticas, por instrumentos que legitimam vontade direta, da supremacia da coletividade com fundamento do adágio dos valores gerais sobre o individual. Conquanto relevantes, são insuficientes para a proteção adequada da sociedade.

A função jurisdicional tem como missão institucional, portanto, exercer o papel de proteção da sociedade, tendo como fundamento a proteção da sociedade da atividade legislativa, da função jurisdicional e afastar qualquer ato atentatória aos direitos fundamentais.

Neste ponto ganha destaque, dentre tantos órgãos jurisdicionais, a Corte Constitucional, com relevante missão de proteção da força normativa da Constituição, proteção do regime de competências, defesa dos direitos fundamentais e o exercício do papel protetor das minorias. Sobre a relevância da Corte Constitucional, no desempenho do Estado

146 BRASIL. Constituição da República Federativa do Brasil de 1988. Disponível em < http://www.planalto.gov.br/ccivil_03/Constituicao/constituicao.htm>. Acesso em: 19 de vo. 2017. Art. 102. Compete ao Supremo Tribunal Federal, precipuamente, a guarda da Constituição, cabendo-lhe: I - processar e julgar, originariamente: 1) a reclamação para a preservação de sua competência e garantia da autoridade de suas decisões; 
A missão deferida da Corte Constitucional, através do exercício da jurisdição constitucional, assenta a necessidade de apontar quais as funções da Corte Constitucional no Estados Constitucionais. A compreensão da contextualização das funções da Corte Constitucional permite análise dos pressupostos de existência da reclamação constitucional, a necessidade da vinculação dos precedentes e em quais funções da Corte ele poderá ser utilizada.

Para além disso, incumbência do Tribunal Constitucional é a defesa da Constituição, para tanto é necessário instrumento para manter a higidez das decisões da Corte. Sendo esse o contexto, a vinculação dos precedentes por força dos arts. 926 e 927 do Novo Código de Processo Civil são constitucionais porque convergem com as funções próprias do Tribunal Constitucional.

\section{REFERÊNCIAS}

BARACHO, José Alfredo de Oliveira. Processo Constitucional. Rio de Janeiro : Forense, 1984. p. 334

CAPELLETTI, Mauro. Repudiando Montesquieu?: a expansão e a legitimidade da "justiça constitucional”. Tradução de Fernando Sá. Revista Forense, Rio de Janeiro, v. 366, p. 127-150, mar./abr. 2003.

DANTAS, Marcelo Ribeiro Dantas. Reclamação constitucional. Porto Alegre: Sergio Antonio Fabris Editor, 2000.

FERREIRA, Pinto. A Corte Constitucional. Revista de Informação Legislativa. Brasília, A. 24, no 95. Jul/set. 1987.

GRAU, Eros Roberto. Ensaio e discurso sobre a interpretação/aplicação do direito. $5^{\mathrm{a}} \mathrm{Ed}$. Malheiros.

HABERMAS, Jurger. Direito e Democracia: Entre facticidade e validade. Vol. I/tradução: Flávio Beno Siebeneichler. Rio de Janeiro: Tempo Brasileiro, 1997.

HORBACH, Carlos Bastide. A nova roupa do Direito Constitucional:Neoconstitucionalismo, pós-positivismo e outros modismos. Revista dos Tribunais. Vol. 859. P.81. maio. 2007. 
LEITE, Glauco Salomão; BREITENBACH, Fábio Gabriel. Racionalidade e segurança na interpretação do Direito: os deveres do juiz e os precedentes no Novo Código de Processo Civil. Revista do Instituto de Hermenêutica Jurídica - RIHJ, Belo Horizonte, ano 14, n. 20, p. 223-243, jul./dez. 2016.

MEDEIROS, Morton Luiz Faria. Jurisdição constitucional exercida pelas cortes constitucionais: Sua importância para consolidação do Estado Democrático de Direito. Revista de Informação legislativa, Brasília, A. 42. Nº 167 jul/set. 2005. P. 341

MENDES, Gilmar Ferreira. Controle de Constitucionalidade: Hermenêutica constitucional e revisão de fatos e prognoses legislativos pelo órgão judicial. Revista de Direito Constitucional e Internacional, Ano 08. Abril-junho. 2000. Editora Revista dos Tribunais.

MORAES, Alexandre. Legitimidade da justiça constitucional. Revista de Informação legislativa. A. $40 n^{\text {o }} 159$ jul/set 2003, p. 49

NERY JUNIOR, Nelson; NERY, Rosa Maria de Andrade. Comentários ao Código de Processo Civil. São Paulo: Revista dos Tribunais, 2015

NOBRE JUNIOR, Edilson Pereira. A jurisdição constitucional e os direitos fundamentais: uma análise em torno do direito ao desenvolvimento. Revista de Direito Administrativo \& Constitucional. Ano. 11. N 46. Out-dez. Editora Fórum: Belo Horizonte.

NOBRE JUNIOR, Edilson Pereira. O direito processual brasileiro e o efeito vinculante das decisões dos tribunais superiores. Revista de Informação Legislativa. A. $37 . \mathrm{N}^{\circ} 148$, out/dez. 2000.

RAMOS, Dirceo Torrecillas. Politização do judiciário e a judicialização da política. Revista de Direito Constitucional e Internacional. Ed Revista dos Tribunais. Ano 08. OutDez. 2000. No 33 . .

TAVARES, André Ramos. Justiça Constitucional e suas fundamentais funções. Revista de Informação Legislativa. A. 43. N. 171. Jul/set. 2006.

TUCCI, José Rogério Cruz e. O regime do precedente judicial no novo CPC. In: DIDIER JUNIOR, Fredie et al. (Coords). Precedentes. Salvador: Juspodium, 2015. 
VELlOSO, Carlos Mário. O Supremo Tribunal Federal, Corte Constitucional: Uma proposta que visa a tornar efetiva a sua missão precípua de guarda da Constituição. Revista de Informação Legislativa. № 120, a. 30, out/dez. 1993.

SILVA, Cecília de Almeida et al. Saídas institucionais ou a força do processo democrático na prevalência da Constituição?. A\&C - Revista de Direito Administrativo \& Constitucional, Belo Horizonte, ano 10, n. 41, p. 123-145, jul./set. 2010.

\title{
OWN FUNCTIONS OF THE CONSTITUTIONAL COURT AND PRECEDENTS: PARAMETERS FOR CONSTITUTIONALITY
}

\begin{abstract}
It addresses the relationship between the functions of the Constitutional Court and the constitutionality of the hypotheses of binding precedents, as provided in art. 926 and 927 of the New Code of Civil Procedure, facing the questions about the unconstitutionality of the hypotheses of art. 927 of the New Code of Civil Procedure. Likewise, the functions of the Constitutional Court and the need for binding and stability of constitutional jurisprudence are dealt with.
\end{abstract}

Keywords: Constitutional Court. Precedents. Constitutional Complaint. 